\title{
Cause of Stomal Obstruction after Gastroenterostomy
}

\author{
I. G. M. CLEATOR,* M.B., CH.B., F.R.C.S., F.R.C.S.ED. ; C. W. A. FALCONER,* M.B., CH.B., F.R.C.s.ED. \\ W. P. SMALL, ${ }^{*}$ CH.M., F.R.C.S.ED., F.R.C.P.ED. ; A. N. SMITH,* M.D., F.R.C.S.ED.
}

Brit. med.F., 1968, 2, 530-532

In the past three years gastroenterostomy with or without vagotomy has been performed in 130 selected cases at the Western General Hospital, Edinburgh. During the same period stomal obstruction due to funnel formation in the mesocolon has been noted in five patients. In all 130 cases the gastroenterostomy was of a standard type: the mesocolon was drawn upwards and a hole made to the left of the middle colic vessels. An oblique opening was made near the greater curvature of the stomach at its most dependent part and a two-layer isoperistaltic anastomosis carried out between the stomach and the first loop of the jejunum $3-4$ in. $(7.5-10 \mathrm{~cm}$.) from the ligament of Treitz. The opening in the mesocolon was attached to the stomach with interrupted sutures almost $\frac{1}{2}$ in. $(1.3 \mathrm{~cm}$.) from the stoma, which admitted two and a half fingers at the end of the operation.

In each of the five patients the course of events was the same (see Table). Case 1 is described as an example.

\begin{tabular}{|c|c|c|c|c|c|c|}
\hline $\begin{array}{l}\text { Case } \\
\text { No. }\end{array}$ & Sex & Age & Diagnosis & Operation & $\begin{array}{l}\text { Onset of } \\
\text { Holdup: } \\
\text { Days after } \\
\text { Operation }\end{array}$ & $\begin{array}{c}\text { Revision } \\
\text { of Procedure }\end{array}$ \\
\hline 1 & $M$ & 27 & $\begin{array}{l}\text { Duodenal } \\
\text { ulcer }\end{array}$ & $\begin{array}{l}\text { Retrocolic gastro- } \\
\text { enterostomy and } \\
\text { truncal vagotomy }\end{array}$ & 10 & $\begin{array}{l}\text { Revision of } \\
\text { gastroenter- } \\
\text { ostomy }\end{array}$ \\
\hline 2 & $\mathrm{~F}$ & 47 & $\begin{array}{c}\text { Duodenal } \\
\text { ulcer }\end{array}$ & $\begin{array}{l}\text { Retrocolic gastro- } \\
\text { enterostomy }\end{array}$ & 8 & $\begin{array}{l}\text { Conversion to } \\
\text { pyloroplasty } \\
\text { and truncal } \\
\text { vagotomy }\end{array}$ \\
\hline 3 & $M$ & 24 & $\begin{array}{c}\text { Duodenal } \\
\text { ulcer }\end{array}$ & $\begin{array}{l}\text { Retrocolic gastro- } \\
\text { enterostomy and } \\
\text { truncal vagotomy }\end{array}$ & 8 & $\begin{array}{l}\text { Revision of } \\
\text { gastroenter- } \\
\text { ostomy }\end{array}$ \\
\hline \multirow[t]{2}{*}{4} & $M$ & 26 & $\begin{array}{l}\text { Duodenal } \\
\text { ulcer }\end{array}$ & $\begin{array}{l}\text { Retrocolic gastro- } \\
\text { enterostomy and } \\
\text { truncal vagotomy }\end{array}$ & 10 & $\begin{array}{r}\text { Conversion to } \\
\text { pyloroplasty }\end{array}$ \\
\hline & $M$ & 62 & $\begin{array}{c}\text { Hiatus } \\
\text { hernia }\end{array}$ & $\begin{array}{l}\text { Repair of hiatus } \\
\text { hernia. Retro- } \\
\text { colic gastro- } \\
\text { enterostomy and } \\
\text { truncal vagotomy }\end{array}$ & 12 & $\begin{array}{r}\text { Conversion to } \\
\text { pyloroplasty }\end{array}$ \\
\hline
\end{tabular}

\section{Case Report}

The patient, a 27-year-old miner, had a 14-year history of ulcer dyspepsia. His mother had a duodenal ulcer. Barium-meal examination showed gross deformity of the duodenal cap with an ulcer crater present. His maximal acid output was $21.9 \mathrm{mEq}$ in the first post-histamine hour. His blood group was $\mathrm{O}+$.

At operation an acutely inflamed anterior duodenal ulcer with marked stenosis was found: truncal vagotomy and a standard retrocolic isoperistaltic gastroenterostomy were performed. After operation he made an excellent recovery, and was taking a light diet on the third day after operation.

On the tenth day he started to vomit. A radiological study with Gastrografin showed distension of the afferent loop and stomach, none of the Gastrografin leaving by the efferent loop.

$\mathrm{He}$ was treated with nasogastric suction and intravenous fluids. After a week there was still no sign of gastric emptying and the patient was again explored. The anastomosis was found enclosed in a funnel of mesocolon with a tight fibrous ring at the base of the funnel. The appearances at first suggested that the anastomosis had slipped up through the hole in the mesocolon; but careful dis-

* General Surgical Unit, Western General Hospital, Edinburgh 4. section of necrotic fat and rigid fibrous material (cut with difficulty by sharp dissection) showed that, in fact, the mesocolon remained sutured firmly to the stomach.

The gastroenterostomy was taken down and the funnel in the mesocolon closed. The gastroenterostomy was then resited and the patient made a good recovery.

\section{Mechanism of Obstruction}

In all five patients the cause of the obstruction was the rigid nature of the fibrous base of the funnel of the mesocolon (see Fig.). This fibrous ring was sufficient to occlude completely the efferent loop, which was flaccid and empty distally. The afferent loop was distended and contained bile. The distension of the afferent loop, within the enclosed ring, pressed on the efferent loop and completed the obstruction of the efferent loop.

The hold-up occurred between 8 and 12 days after the first operation in each case. This is the time necessary for the formation of fibrous tissue.

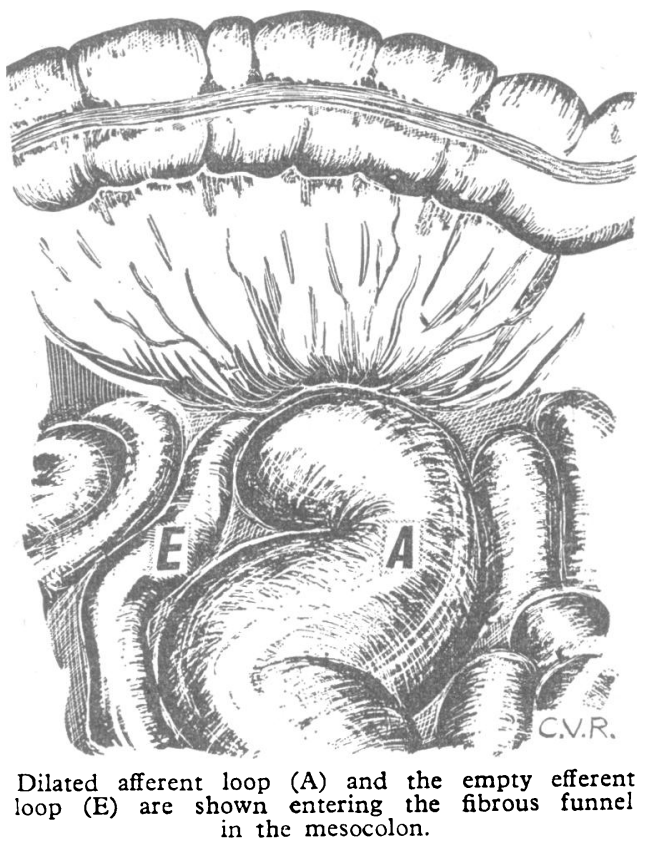

\section{Discussion}

The first case of stomal obstruction was described by Wölfler (1881). He thought that the obstruction was caused by the spur formed when the jejunum was pulled up to attach it to the stomach, thus directing bile and pancreatic juice into the stomach instead of into the efferent loop. This may still be relevant in some cases.

Another cause of gastroenterostomy hold-up is jejunogastric intussusception of the efferent loop. This was first described 
by Bozzi (1914), and since then more than 150 cases have been recorded (Devor and Passaro, 1966).

Moynihan (1921) recorded many complications of gastroenterostomy, including herniation of a loop of small bowel through an incompletely sutured mesocolon, twisting of the afferent and efferent loops of jejunum, and adhesions to the efferent loop, but did not mention the occurrence of any funnel effect within his experience or that of his contemporaries.

Eusterman et al. (1942) reviewed a series of 62 patients who had a non-functioning stoma demonstrated radiologically at varying periods after simple gastroenterostomy. Forty-eight of this group were due to stomal or jejunal ulceration-a cause not seen of ten now owing to better selection for this operation. In six patients no abnormality was found at operation, but in the remaining eight the cause was ascribed to mechanical twisting of the loops or adhesions.

In posterior Billroth II gastrectomies, as in simple gastroenterostomies, it has long been recognized that loop constriction by the transverse mesocolon can occur. This is, however, usually ascribed to the anastomosis "slipping up" through the hole in the mesocolon. Hibner and Richards (1958) had 17 patients with this type of obstruction out of 259 Billroth II gastrectomies. Mullen (1958), however, pointed out that this complication did not occur if the hole in the mesocolon was firmly attached high up on the gastric remnant.

Various other mechanical causes of stomal obstruction have been found over the years. Acute pancreatitis, anastomotic leakage, and too small a stoma are mentioned by Hibner and Richards (1958) as causing obstruction, and internal hernia is described by Stammers (1955).

Stammers and Williams (1963) record a type of stomal obstruction due to omental fat necrosis in retrocolic gastrojejunal anastomosis. They describe this as a rare condition in which the thickened adhesive mesocolon gains a rigid stranglehold on the stomal region and causes obstruction. It could be that this appearance is a later stage of the mechanism of obstruction which we are describing.

In addition to these mechanical factors localized oedema is incriminated by some authors as a cause of obstruction of the stoma. Barden et al. (1937) caused delayed emptying time by inducing hypoproteinaemia in dogs who had had partial gastrectomies. Chauncey and Gray (1943), however, demonstrated that the serum protein concentration rose from the seventh to the thirteenth postoperative day while the degree of gastric retention increased. Prohaska et al. (1954), too, feel that the concept that stomal oedema is due to hypoproteinaemia is untenable, as this postulates a "so-called localized oedema," which always involves the efferent loop in a patient who does not show oedema anywhere else.

Hypokalaemia is also accepted as an important cause of prolonged postoperative gastric retention. Deficiency of potassium inhibits intestinal muscle activity by interfering with acetylcholine formation and neuromuscular conduction (Harkins and Nyhus, 1962). This was, however, not a factor in our patients, who were given potassium supplements in their intravenous infusion to maintain a physiological level.

\section{Cause of Obstruction}

We must ask ourselves why this complication is first noted now, and not in the heyday of gastroenterostomy at the beginning of this century. The important factor seems to be the size of the stomach. The first gastroenterostomies were performed on patients with large distended atonic stomachs due to pyloric obstruction or stenosis. Under these circumstances it would seem that there would be no tendency to pull the anastomosis upwards and tent the mesocolon.

Nowadays extreme examples of stenosis and gastric distension are rarely seen, and operation is being used to treat the ulcer rather than its complications. Thus, as in the five cases recorded here, the stomach may be small. In addition, the stomach is kept empty before and after surgery by nasogastric suction. The tendency might be, therefore, for the relatively small stomach to pull upwards on the mesocolon, tenting it. After a week to 10 days the oedema and inflammatory reaction in the funnel of mesocolon around the anastomosis, which is probably present in all patients after surgery, is replaced by fibrous tissue, and thus contracts to form a fibrous obstructing ring at the base.

\section{Prevention}

Two possible changes in the management of gastroenterostomy as practised by ourselves and others might prevent this complication.

Nasogastric aspiration after operation could be abandoned or curtailed to the few hours necessary to ensure that gross gastric dilatation, with its attendant risks, does not occur. Removal of the nasogastric tube immediately after operation and early feeding could be used.

It may also be advisable to avoid gastroenterostomy if a patient who is a candidate for gastric surgery is found to have a small stomach.

\section{Treatment of Stomal Obstruction}

We would suggest the following lines of treatment for patients with stomal obstruction. Once the diagnosis of stomal obstruction is made on clinical and radiological grounds a period of conservative treatment should be tried. We have had three other patients in this series with an obstruction which resolved on this treatment. If the obstruction persists after a week of this management, as evidenced by lack of gastric emptying clinically and radiologically, the patient should be operated on.

If the cause of the obstruction is found to be the fibrous funnel of the mesocolon one of two lines of treatment is effective, the choice depending on the state of the duodenal ulcer. If the duodenal ulcer is quiescent at the time of this operation the gastroenterostomy can be dismantled and the jejunum and stomach wall reconstituted. A pyloroplasty can then be performed, with the addition of vagotomy if this was not done at the first operation.

If, however, the duodenal ulcer appears active at the time of operation, the gastroenterostomy should be dismantled, the funnel of mesocolon closed, and the gastroenterostomy resited.

The first of these alternatives is preferable on theoretical grounds as a remedial operation, since there is a chance of further trouble from a gastroenterostomy in a group susceptible to such complications. In practice, however, resiting of the gastroenterostomy has been effective in the two patients on whom it was performed.

\section{Summary}

Gastroenterostomy with or without vagotomy was performed in 130 selected cases over a three-year period. Five of these patients required subsequent surgery for stomal obstruction caused by the mesocolon. In these patients, (1) the obstruction occurred between eight and 12 days after operation, (2) the findings at reoperation were that the mesocolon remained firmly sutured to the stomach but a fibrous funnel had formed in the mesocolon, causing the obstruction. The treatment of choice seems to be conversion to a pyloroplasty, with the addition of vagotomy if this has not been carried out at the first operation. 
It is suggested that this complication may occur in patients with small stomachs, but it may be avoided by choosing an alternative operation in such cases.

We wish to thank Mr. Vaughan Ruckley, F.R.C.S.Ed., for the diagram.

\section{REFERENCES}

Barden, R. P., Ravdin, I. S., and Frazier, W. D. (1937). Amer. F. Roentgenol., 38, 196

Bozzi, E. (1914). Cited by Irons and Lipin, 1955.

Chauncey, L. R., and Gray, H. K. (1943). Gastroenterology, 1, 72
Devor, D., and Passaro, E., jun. (1966). Ann. Surg., 163, 93.

Eusterman, G. B., Kirklin, B. R., and Morlock, C. G. (1942). Amer. 7

dig. Dis., 9, 313 .
Harkins, H. N., and Nyhus, L. M. (1962). Surgery of the Stomach and Duodenum, p. 549 . Boston.

Hibner, R., and Richards, V. (1958). Amer. F. Surg., 96, 309.

Irons, H. S., jun , and Lipin, R. J. (1955). Ann. Surg., 141, 541.

Moynihan, Sir Berkeley (1921). Essays on Surgical Subjects. Philadelphia and London.

Mullen, B. P. (1958). Amer. 7. Surg., 96, 318.

Prohaska, J. V., Govostis, M. C., and Kirksteins, A. (1954). Arch. Surg., 68,491 .

Stammers, F. A. R. (1955). Ann. roy. Coll. Surg. Engl., 17, 373.

Stammers, F. A. R., and Williams, J. A. (1963). Partial Gastrectomy,

Wöfler, A. (1881). Zbl. Chir., 8, 705.

\title{
Outbreak of Coxsackie Type B2 Virus in a Children's Home in Newcastle Upon Tyne
}

\author{
JOAN CARMICHAEL,* M.B., B.S. ; ROSEMARY MCGUCKIN, $†$ F.I.M.L.T. \\ P. S. GARDNER, $\dagger$ M.D., DIP.BACT.
}

Brit. med. F., 1968, 2, 532-533

Coxsackie group $\mathbf{B}$ viruses are seldom associated with respiratory tract infection. However, an outbreak of summer febrile illness caused by Coxsackie type B2 virus without acute central nervous symptoms or pleurodynia (Heggie et al., 1960) and a similar illness in which Coxsackie B3 virus was found (Kendall et al., 1960) have been described. In both instances virus isolation was higher in ill children than in those without illness; throat swabs were more often positive than faeces.

A report suggesting that Coxsackie type B5 virus was a cause of upper respiratory infection, but not necessarily of the lower tract, has also been published (Vargosko et al., 1962). This view has not been generally accepted; other workers (Eckert et al., 1967) have incriminated Coxsackie group B viruses in lower respiratory tract infections. Similarly, the Public Health Laboratory Service Report (1967) on 900 cases of Coxsackie B5 virus infection found that $15 \%$ were associated with respiratory disorders, ranging from cold, sore throat, croup, and pharyngitis to pneumonia, but there is still a need for additional evidence.

This communication describes an outbreak of respiratory disease associated with Coxsackie type B2 virus in a residential nursery.

\section{The Home}

The home is a converted nineteenth-century mansion, and 80 children between the ages of 2 and 15 live in the same house. Twenty toddlers live separately and have their own play-room, dining-room, and eight-bedded dormitories. They are looked after by a sister with nursery training and four lay helpers. This staff comes into contact with the other staff of the house at mealtimes. There is also an infants' nursery about 300 yards $(275 \mathrm{~m}$.) away from the main building, where 10 infants between 6 weeks and 1 year and five children aged between 1 and 2 live under the care of two trained sisters with a variable amount of help from lay workers from outside the home.

\section{The Outbreak}

The outbreak occurred in the group of 20 toddlers between the ages of 2 and 5 years. It began with a 3-year-old girl who was playing in the garden with the others in her group. She suddenly started to cough violently and became blue. Obviously ill, she was thought to have inhaled part of a small plastic toy, and was sent immediately to hospital and admitted to the children's ward. Here she was found to be suffering from an acute respiratory infection, with a temperature of $101^{\circ} \mathrm{F}$. $\left(38.3^{\circ}\right.$ C.), tonsillitis, and laryngeal stridor. There was no evidence of a foreign body. She was treated with ampicillin and steam inhalations and made a complete recovery in five days. Unfortunately, full virological investigations were not carried out.

The next morning seven children in the toddlers' nursery were ill with fever, drowsiness, dry spasmodic cough, vomiting, and diarrhoea. All had signs of upper respiratory tract infection-that is, rhinitis, pharyngitis, and conjunctivitis. The next day a further nine children had developed similar symptoms and signs. The illness lasted for two to three days, and, after apparent improvement for two to three days, six children again became ill with the same symptoms of fever, drowsiness, cough, vomiting, and diarrhoea. On the second day of the outbreak a 16-year-old girl who helped in the nursery also became ill with cough, fever, and right-sided pleural pain. Signs of upper respiratory tract infection were present but there were no abnormal physical signs in her chest. After four days she was sent home to convalesce, but had a mild recurrence of symptoms a week after the onset of illness.

A typical history of the disease in the children is illustrated by a 4-year-old boy (Case 5). The onset was sudden. When he complained of feeling ill he was put to bed, where he vomited. On examination he was found to have a temperature of $101^{\circ} \mathrm{F}$. $\left(38.3^{\circ} \mathrm{C}\right.$.), to be extremely drowsy, to have mild conjunctivitis and pharyngitis, but no meningism or abnormal signs in the central nervous system. There were no abnormal signs in the chest. There was some improvement by the next day, but two days after the onset of his illness he relapsed with fever, vomiting, and cough. By the fifth day he had completely recovered.

The symptoms and the virological results are summarized in the Table.

All the children were treated with ampicillin, $125 \mathrm{mg}$. four times a day for seven days. The older girl was given $250 \mathrm{mg}$. of ampicillin four times a day for a week. The antibiotics did not seem to produce any dramatic improvement or prevent the occurrence of relapses.

* General Practitioner, Newcastle upon Tyne.

t Department of Virology, University of Newcastle upon Tyne, and the Royal Victoria Infirmary, Newcastle upon Tyne. 